\title{
PENYULUHAN PENGGUNAAN OBAT YANG BENAR DAN PEMERIKSAAN GOLONGAN DARAH DI POS BELAJAR DUTASIA TANGERANG
}

\author{
Jessica Novia ${ }^{1}$, Dela Rosa ${ }^{1}$, Marcelia Sugata ${ }^{2}$, Denny Juvi ${ }^{2}$ \\ ${ }^{1}$ Program Studi Farmasi Universitas Pelita Harapan \\ ${ }^{2}$ Program Studi Biologi Universitas Pelita Harapan
}

jessica.novia@uph.edu,dela.rosa@uph.edu,marcelia.sugata@uph.edu,dennyjuvi@gmail.com

\begin{abstract}
Abstrak
Kesadaran masyarakat Indonesia akan betapa pentingnya kesehatan semakin meningkat, sehingga memicu peningkatan Upaya Pengobatan Sendiri (UPDS) atau swamedikasi. Sampai saat ini masih banyak masyarakat yang belum mengetahui cara penggunaan obat yang tepat dan rasional sehingga sering terjadi kesalahan dalam pengobatan yang mengakibatkan efek yang tidak diharapkan dari obat tidak tercapai, overdosis maupun timbulnya efek samping yang tidak diinginkan. Oleh karena itu, masyarakat perlu mendapatkan penyuluhan yang tepat agar masalah-masalah terkait kesalahan pengobatan dapat dihindari. PkM yang dilaksanakan meliputi penyuluhan mengenai penggunaan obat yang tepat dan rasional, termasuk di dalamnya pengertian tentang klasifikasi obat, macam-macam sediaan obat dan cara penggunaannya, cara penyimpanan obat serta pembuangan obat yang sudah rusak atau kadaluarsa. Pemeriksaan golongan darah juga dilakukan untuk mencegah risiko kesehatan dan dalam keadaan darurat jika diperlukan transfusi darah. Kegiatan ini berlangsung selama 1 (satu) hari diikuti oleh ibu-ibu pembina Pos Belajar Dutasia dan anak-anak. Para peserta menunjukkan ketertarikan yang tinggi dan respon yang positif selama kegiatan berlangsung. Selain mendapatkan manfaat dari penyuluhan obat, peserta juga mendapatkan informasi terkait golongan darah masing-masing yang sebelumnya belum diketahui.
\end{abstract}

Kata Kunci : edukasi, golongan darah, obat, rasional

\section{PENDAHULUAN}

Saat ini masyarakat Indonesia lebih menyadari betapa pentingnya kesehatan bagi diri mereka sendiri dan keluarganya. Hal itu memicu banyak upaya yang dilakukan untuk menjaga kesehatan dan mengobati penyakit dan salah satunya adalah dengan swamedikasi atau Upaya Pengobatan Diri Sendiri (UPDS). Swamedikasi merupakan tindakan yang dilakukan oleh individu yang bertujuan untuk mengobati segala keluhan pada diri sendiri dengan obat-obatan yang dapat dibeli bebas di apotek atas inisiatif sendiri dan tanpa melakukan pemeriksaan ke dokter.
Apabila dilakukan dengan tepat dan rasional, maka swamedikasi dapat meningkatkan pemeliharaan kesehatan secara nasional. Namun jika sebaliknya, swamedikasi dapat menyebabkan masalah kesehatan. Masalah yang dapat timbul jika terjadi kesalahan dalam penggunaan obat adalah tidak tercapainya efek obat yang diinginkan, timbulnya efek samping yang tidak diinginkan, timbulnya penyakit lain, kelebihan konsumsi obat (overdosis). Hal ini dapat disebabkan karena kurangnya pemahaman masyarakat tentang penggunaan obat yang tepat dan rasional, kurangnya informasi yang memadai tentang penggunaan obat yang didapat dari tenaga kesehatan, serta kurangnya

Pangan dan Kesehatan

558 
kesadaran dan kemampuan masyarakat untuk mencari informasi melalui sumber yang tepat.

Berdasarkan Hasil Riset Kesehatan Dasar (Riskesdas) 2013 menunjukkan bahwa 35,2\% rumah tangga menyimpan obat untuk swamedikasi. Dari $35,2 \%$ rumah tangga yang menyimpan obat, $35,7 \%$ di antaranya menyimpan obat keras dan $27,8 \%$ diantaranya $86,1 \%$ antibiotik yang diperoleh tanpa resep. Hal ini memicu terjadinya masalah kesehatan baru, khususnya resistensi bakteri.

Berdasarkan masalah yang dijabarkan di atas, maka masyarakat perlu mendapatkan penyuluhan tentang penggunaan obat yang tepat dan rasional.

Golongan darah adalah ciri khusus dari suatu individu karena adanya perbedaan jenis karbohidrat dan protein pada permukaan membrane sel darah. Ada dua jenis penggolongan darah yang paling penting, yaitu penggolongan darah $\mathrm{ABO}$ dan Rhesus. Golongan darah merupakan identitas diri seseorang. Tidak hanya itu saja, golongan darah juga penting untuk diketahui karena berkaitan dengan kesehatan tubuh dan risiko suatu penyakit. Namun, masih banyak orang yang tidak peduli dengan golongan darahnya. Selain itu, dengan mengetahui golongan darah, maka akan lebih mudah bagi tenaga kesehatan untuk melakukan transfusi darah saat diperlukan.

Masyarakat di Kampung Dhumpit, Gandasari, Tangerang, Banten belum memiliki akses yang cukup baik terhadap informasi kesehatan, termasuk di dalamnya penggunaan obat. Dalam Era JKN (Jaminan Kesehatan Nasional) ini, masyarakat lebih termotivasi untuk melakukan pemeriksaan kesehatan secara rutin di pusat pelayanan kesehatan setempat dan hal ini menjadi sebab peredaran obat yang cukup banyak di masyarakat. Namun penggunaan obat yang semakin banyak ini belum didiukung dengan pengetahuan masyarakat mengenai cara mengkonsumsi obat yang tepat dan rasional, cara penyimpanan dan pembuangan obat yang baik dan aman. Pemberian penyuluhan terkait penggunaan obat yang tepat dan rasional menjadi kebutuhan masyarakat agar terhindar dari dampak buruk yang dapat terjadi akibat kesalahan penggunaan obat. Sebagian besar masyarakat juga belum mengetahui golongan darahnya. Melalui kegiatan pemeriksaan golongan darah ini, diharapkan masyarakat lebih antusias untuk memeriksakan golongan darahnya, sehingga jika sewaktu-waktu data tersebut diperlukan secara cepat, tidak perlu dilakukan lagi pemeriksaaan yang akan memakan waktu.

\section{METODE}

Kegiatan pengabdian masyarakat dalam bentuk "Penyuluhan Penggunaan Obat Yang Benar dan Pemeriksaan Golongan Darah di Pos Belajar Dutasia Tangerang" dilaksanakan pada dilaksanakan pada tanggal 31 Agustus 2018 pada Pk. 14.00 - 16.00 WIB di Pos Belajar Dutasia Kampung Dhumpit, Gandasari, Tangerang, Banten.

Metode pelaksanaan PkM meliputi penyuluhan mengenai penggunaan obat yang tepat dan rasional, termasuk di dalamnya pengertian tentang klasifikasi obat, yaitu obat bebas, obat bebas terbatas, obat wajib apotek, obat keras; macam-macam sediaan obat dan cara penggunaannya; cara penyimpanan obat serta pembuangan obat yang sudah rusak atau kadaluarsa. Penyuluhan juga akan diikuti dengan peragaan cara penggunaan sediaan obat seperti tablet, kapsul, larutan, suppositoria, ovula, spray.

Selain kegiatan penyuluhan terkait penggunaan obat yang benar, juga akan dilakukan pemeriksaan golongan darah $\mathrm{ABO}$. Bahan yang digunakan untuk pemeriksaan golongan darah adalah reagen golongan darah, yang terdiri dari serum anti-A, serum anti-B dan serum anti-AB. Prinsip pemeriksaan golongan darah adalah berdasarkan reaksi antigen-antibodi berupa penggumpalan (aglutinasi). Peserta yang mengikuti kegiatan pemeriksaan golongan darah akan mendapatkan kartu golongan darah yang menunjukkan hasil pemeriksaan golongan darah.

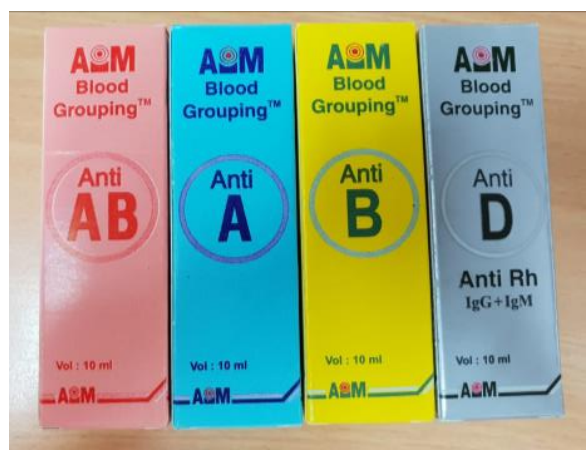

Gambar 1. Reagen golongan darah

Pangan dan Kesehatan 


\section{HASIL DAN PEMBAHASAN}

Peserta sebanyak 49 orang yang terdiri dari ibuibu dan anak-anak mengikuti kegiatan dari awal sampai akhir.

Kegiatan diawali dengan kata pembuka dari ketua kegiatan dan perkenalan tim pelaksana kegiatan kepada peserta. Kegiatan dilanjutkan oleh anggota panitia dengan penyuluhan mengenai cara penggunaan obat yang tepat dan rasional dan pentingnya mengetahui golongan darah, serta sesi tanya jawab. Penyuluhan dilakukan dengan menggunakan media pembantu yang sudah disiapkan seperti $x$-banner dan poster.

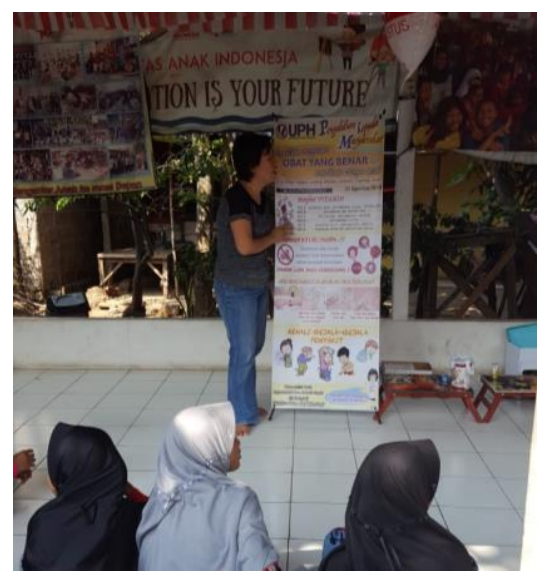

Gambar 2. Suasana penyuluhan penggunaan obat

Kegiatan dilanjutkan dengan pemeriksaan golongan darah yang dilakukan oleh seluruh panitia untuk seluruh peserta kegiatan. Pemeriksaan golongan darah juga dilakukan secara aseptik dengan menggunakan alcohol swab, sarung tangan, dan masker.

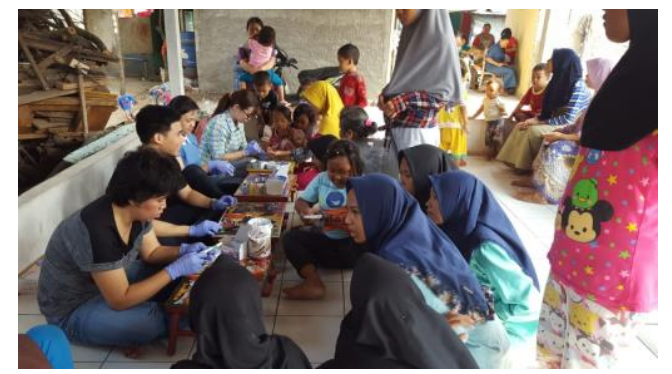

Gambar 3. Kegiatan pemeriksaan golongan darah
Setiap peserta yang mengikuti pemeriksaan golongan darah akan mendapatkan kartu golongan darah.

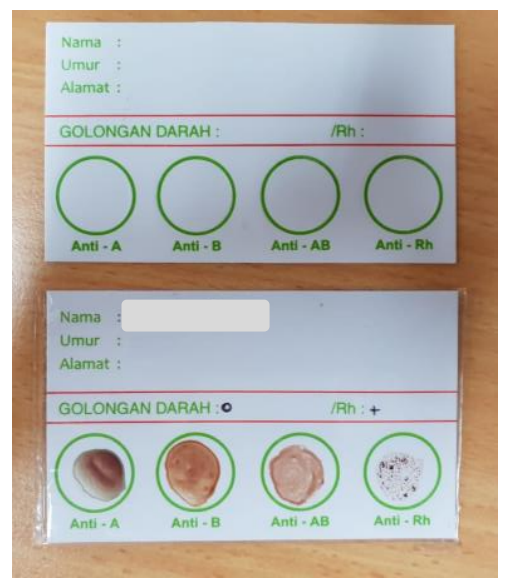

Gambar 4. Kartu golongan darah

Penyuluhan kemudian diakhiri dengan penyerahan bingkisan dari ketua panitia terhadap perwakilan dari Pos Belajar Dutasia sebagai bentuk apresiasi.

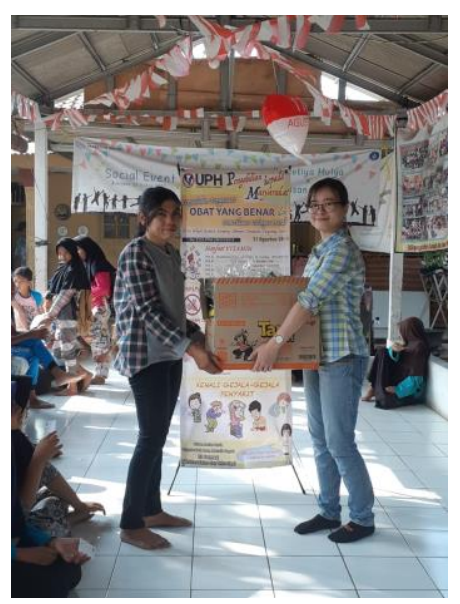

Gambar 5. Penyerahan bingkisan

Dalam pelaksanaan kegiatan tidak dilakukan perekapan data secara kuantitatif sehingga tidak didapatkan data untuk hasil kegiatan. Akan tetapi, setelah penyuluhan dilakukan sesi tanya jawab dilakukan secara dua arah, sehingga panitia menanyakan kembali kepada peserta mengenai halhal yang sudah disampaikan seperti definisi dan klasifikasi obat, macam-macam sediaan obat dan cara penggunaannya, serta tata cara penyimpanan obat dan pembuangan obat yang rusak atau 
kadaluarsa. Pada saat pemeriksaan golongan darah, setiap peserta mendapatkan kartu golongan darah hasil uji yang dilakukan, sehingga setiap peserta dapat menyimpan dan mengingat golongan darah mereka masing-masing.

\section{KESIMPULAN}

Kegiatan penyuluhan dan pemeriksaan golongan darah berlangsung dengan baik, peserta kegiatan juga kooperatif dan mengikuti kegiatan yang berlangsung dengan antusias. Pemahaman masyarakat mengenai obat secara umum dan swamedikasi masih perlu ditingkatkan. Oleh karena itu, untuk keberlanjutan PkM berupa penyuluhan dapat diberikan kepada ibu rumah tangga, karena ibu yang berperan besar dalam swamedikasi rumah tangga dan pemberian kuisioner sebelum dan sesudah penyuluhan perlu dilakukan untuk data kuantitatif luaran.

\section{UCAPAN TERIMAKASIH}

Terima kasih kepada Universitas Pelita Harapan dan Pos Belajar Dutasi yang telah memberikan kesempatan kepada tim untuk dapat melaksanakan kegiatan PkM ini.

\section{REFERENSI}

Anief, Moh. 2012. Farmasetika. Yogyakarta: UGM Press.

Kementerian Kesehatan RI. 2013. Riset Kesehatan Dasar. Bagian Penelitian dan Pengembangan Kesehatan, Kementerian Kesehatan RI.

Tortora, Gerard J dan Bryan Derrickson. 2012. Principles of Anatomi \& Physiology $13^{\text {th }}$ Edition. USA: John Wiley and Sons Inc. 